\title{
UKRAINIAN LITERATURE BY WOMEN WITHIN THE CONTEXT OF COLONIALISM AND POST- COLONIALISM
}

\author{
Radana MERZOVA ${ }^{1}$
}

\begin{abstract}
The article focuses on the roots of Ukrainian feminism, outstanding personalities involved in the development of Ukrainian literature and well-known contemporary female writers who interpret the colonial and postcolonial thinking in their works. The article compares the differencies in the development of feminism in the eastern and western Ukraine. The most important Ukrainian feminists are presented as well as their opinion streams and their works of literary criticism. The theme of women has been transformed in contemporary literature; therefore we focus mainly on the works of 20th century. In addition to women's issues we found concrete manifestations of anti-colonial and post-colonial resistance in the works of these Ukrainian authors across of time. The manifestations are based on the denouncement of imperialism. Contemporary Ukrainian feminism is re-evaluating the position of women in society in connection with the cultural and social situation and at the same time takes into account the political context within the particular stages of the historic development of the state. The paper gives examples of postcolonial mythologization of Ukrainian nation, formation of Ukrainian identity by activation of historical memory. In conclusion, the paper introduces a new heroine in Ukrainian prose - woman of complete subjective expressions, an open woman, sexually aware \& intellectually mature.
\end{abstract}

Keywords: Ukrainian feminism, contemporary Ukrainian female writers, colonial and postcolonial context in contemporary literary works, Lesia Ukrainka, Olena Teliha, Lina Kostenko, Marie Matios and Oxsana Zabuzhko.

${ }^{1}$ Ph.D. Palacky University, Faculty of Art, Department of Slavonic Studies, radana.merzova(at)upol.cz 


\title{
SÖMÜRGE VE SÖMÜRGE SONRASI DÖNEM BAĞLAMINDA UKRAYNA EDEBIYATINDAKI KADINLAR
}

\begin{abstract}
ÖZ
$\mathrm{Bu}$ çalışma, Ukrayna Feminizmin köklerine, Ukrayna edebiyatının gelişimininde rol oynayan şahsiyetlere ve çalışmalarında sömürge ve sömürge sonrası düşünceyi yorumlayan tanınmış çağdaş kadın yazarlara odaklanmaktadır. Bu makalede, Doğu ve Batı Ukrayna'daki feminizmin gelişimindeki farklılıklar karşılaştırılmaktadır. Ukraynalı bazı önemli feministler, fikir akımlarına etkilerinin yanı sıra edebi eleştiri eserleriyle birlikte takdim edilmektedir. Kadın teması günümüz edebiy atında dönüşüme uğramıştır, bu sebeple bu makalede ağrlıklı olarak 20. yüzyıl es erlerine odaklanılmıștır. Kadınların sorunlarına ek olarak, bu dönemdeki Ukraynalı yazarların çalışmalarında anti sömürge ve sömürge sonrası direnişe ait somut manifestolar da bulunmaktadır. Bu manifestolar emperyalist ihlallere dayanmaktadır. Çağdaş Ukray na feminizmi tarafından kadınların toplumdaki yeri kültürel ve sosyal durumla bağlantılı olarak yeniden değerlendirilmekte ve aynı zamanda devletin tarihsel gelişiminin belirli aşamaları dâhilinde siyasi şartlar da hesaba katılmaktadır. Bu çalışma, Ukrayna halkının sömürge sonrası mitleştirme ve tarihsel belleğin canlandırılması yoluyla Ukrayna kimliğinin oluşumu örneklerine yer vermektedir. Sonuç bölümünde, Ukrayna düzyazısında yeni bir kadın kahraman cinselliğinin farkında ve entelektüel olarak olgun, açık bir kadın- tanıtılmaktadır.
\end{abstract}

Anahtar Kelimeler: Ukrayna Feminizmi, Çağdaş Ukraynalı kadın yazarlar, sömürge sonrası dönem, Lesia Ukrainka, Olena Teliha, Lina Kostenko, Marie Matios, Oxsana Zabuzhko.

Merzova, Radana. "Ukrainian Literature By Women Within The Context Of Colonialism And Post-Colonialism". idil 6.29 (2017): 247-261.

Merzova, R. (2017). Ukrainian Literature By Women Within The Context Of Colonialism And Post-Colonialism. idil, 6 (29), s.247-261. 
Ukrainian feminism has it roots back in the end of the 19th century when Nataliia Kobrynska founded the first Ukrainian women's movement in western Ukraine (in Galicia, 1884) and began to publish the almanacs Перший вінок (Тhe First Garland, 1887 in Lviv). The women's movement was first and foremost a reaction to human injustice and the government's unwillingness to change the feudal system of serfdom. Women not only fought for their rights, but also for the rights of their fellow-citizens and consequently became an important part of society. Nataliia Kobrynska presented her feminist views by means of both artistic and publishing activity dealing with questions of the position of women in society, the is sue of education, the use of free time for working women as well as issues related to the international women's movement. Olena Pchilka, a renowned Ukrainian writer and translator and the mother of Lesia Ukrainka, was the co-publisher of the almanacs and a financial supporter of Kobrynska. Dniprova Chaika, Liudmyla Starycka, Uliana Kravchenko, Anna Pavlyk, Olesia Bazhanska and others contributed to the almanac. Olha Kobylianska, the founder of Товариства руських жінок на Буковині (Association of Ruthenian Women in Bukovina) was an extremely important figure in literary feminism in Bukovina around the turn of the 20th century. The central theme of her work became moral-ethical questions in the lives of the educated classes, the complicated position of women of "the middle class" and social inequality in society in general.

The situation was completely different in eastern Ukraine (known as Slobidska Ukraine in the 17th and 18th centuries). This part of Ukraine, which had been colonized by the Russian Empire as of the end of the 18th century, had completely different economic, social and political conditions. The original Ukrainian population had been Russianized, culturally suppres sed and the economy had been impacted by the crisis of the feudal serf system in the first half of the 19th century, which hampered further social, economic and political development. The associations linked with the feminist movement in eastern Ukraine were Київське товариство оборони жінок (Kiev Association of Defence of Women, analogically Odessa, Kharkiv).

Apart from the struggle to obtain basic human rights for women, first and foremost voting rights and education over the course of World War I and the revolutionary years of 1917-1921, women worked in various organisations which helped, for example, with escape of prisoners, they were employed in hospitals; young women even participated in battles and served in the army. A branch of liberal feminism developed in the between-the-wars period in western Ukraine. The most significant association in Galicia was Союз Українок (Ukrainian women Union), along with Жіноча громада (Community of Women) and Українське товариство жінок з вищьюю освітою (Ukrainian Association of Women with University 
Education). The Polish government banned Ukrainian women Union as part of the repressive steps during the occupation of western Ukraine in the year 1939 and the political organisation Дружина кнагині Ольги (The Wife of Princess Olga) came into being in its place. The formal equality in terms of the political rights of men and women allowed women to become involved in political activities and consequently Olena Levčanivska (born 1881, Volhynia) was elected into the Polish Senate in the year 1922, Milena Rudnycka (born 1892, Zborov) into the Polish Parliament in the year 1928 and Olena Kysilevska (born 1869, Monastyrska) into the Senate. The women's periodicals Жіноча доля (Women's Fate, (1932-1939), Жіноча воля (Women's Will, (1932-1939), Жіночий голос (Women's Vote, (1931-1939), Нова хвиля (A New Wave, (1925-1939) and others held an important role in the betweenthe-wars period. After the annexation of the eastern parts of Poland by the Soviet Union in the year 1939, the activities of the associations were forbidden. None of the feminist organisations were allowed to develop within the territory of Ukraine during the period of Communist rule and issues of the women's movements and feminist questions were viewed as having been completely solved. The role of women in Communist ideology was clearly defined ahead of time (no religious freedom, work and family regulations, adherence to the Ukrainian branch of Komsomol, etc.) and social discussion of this theme was a closed topic.

After obtaining independence in 1991, gradual returns to the principles of liberal feminism come about, women's organisations are renewed, in particular Союз украӥнок (Ukrainian Union) and new ones such as (Фемен (Femen) in the year 2008) emerge.

The theme of women is being transformed in contemporary literature. In the Romantic period women were traditionally written about as a mother, first and foremost, a virtuous girl who symbolized purity, love and helplessness (the figures of Kateryna in the work of Taras Shevchenko, Natalka Poltavka by Ivan Kotliarevsky or Marusia Churai Kvitka-Osnovianenko. Women are here viewed as complex beings with a complicated psyche and developed intuition. Women are the subject of physical attraction a sexual objects who have the rights to have feelings and wishes and have the right to be unique (in the work of $Я$, Мілена (Me, Milena) by Nila Zborovska or Українська реконкіста (Ukrainian Reconquest) by Oksana Zabuzhko and many others).

Contemporary Ukrainian feminism is re-evaluating the position of women in society in connection with the cultural and social situation and at the same time including the political context within the particular stages of the historic development of the state. The areas of interest include expression of anti-colonialism and postcolonialism in the work of female Ukrainian authors. Ukrainian feminist critics are 
primarily interested in re-evaluating earlier literary traditions, changing established claims and providing new perspectives and theories. Next to this is gynocriticism, which is concerned with women as the authors of literary texts, that is the exploration of literature written by women from the position of feminist literary criticism.

The majority of the feminist studies are of an interdisciplinary character. Solomiia Pavlychko, Vira Aheieva, Tamara Hundorova and Oksana Zabuzhko rank among the most important female literary critics. Their key work and views will be presented in the following paragraphs.

According to Solomiia Pavlychko, a renowned writer, literary scholar, translator and professor at the Kyiv-Mohyla Academy and a guest professor of Ukrainian literature at Harvard University in the USA, the focus on feminism in Ukrainian literature is "an unalterable process in the framework of the democratization and modernization of society. Ukrainian literature began to find itself in the position of the subject of focus of feminist studies" [ПАВЛИЧКО 2002: 48]. The focus of her interest, apart from feminist themes, became the work of Ahatanhel Krymsky - Націоналізм, сексуальність, орієнталізм: складний світ Агатангела Кримського (Nationalism, Sexuality, Orientalism: the Complex World of Ahatanhel Krymsky, 2000, 2001). Her other important works include Дискурс модернізму в украӥнській літературі (The Discourse of Modernism in Ukrainian literature, 1997, 1999), Теорія літератури (Literary Theory, 2002) and Фемінізм: статті, дослідження, бесіди та інтерв'ю (Feminism: Articles, Research, Conversations and Interviews, 2002). Solomiia Pavlyčko in the last mentioned book pointed out the need to disband myths concerning the position of women in society and in Ukrainian literature. The first of these myths is the claim that women occupy an important position in society, and this at the time of the Cossack movement, the Hetmanate arrangement of the country, the Russian Empire, Austria-Hungary and even in the Soviet Ukraine. In actuality, women could only and exclusively express themselves in visual arts. The second myth is the claim that Ukrainian culture is female, effeminate, since it is weak, anti-intellectual and irrational. The third myth views women as the generational object only presented in Ukrainian literature from a man's perspective. Positive female characteristics were evaluated on the basis of the perceptions of men. A woman was only viewed as a male supplement, the embodiment of his desires or in opposite case as an object of aggression and hatred.

Vira Aheieva, professor at the Kyiv-Mohyla Academy, is focused generally on stylistic differentiations in Ukrainian literature of the $20^{\text {th }}$ century, interpreting aspects of Ukrainian literature and culture from the perspective of feminist theory: Жіночий простір: Феміністичний дискурс украӥнського модернізму ( Women's space: Feminist discourse of Ukrainian modernism, 2003). Aheieva is the author of an 
anthology of Ukrainian prose Пам'ять подвигу: Українська воєнна проза 60-80-х років (A Feat of Memory: Ukrainian Military Prose 1960s -1980s, 1989), Апологія модерну: обрис XX віку (A Modern Apology: An Outline of the $20^{\text {th }}$ Century, 2011) and encyclopedia works on Ukrainian modernists Українська імпресіоністична проза (Ukrainian Impressionist Prose, 1994), Київські неокласики. Українські мемуари (Kiev Neoclassicism. Ukrainian Memoirs, 2003).

The monograph by Tamara Hundorova entitled Femina melancholica. Cmamb і культура в гендерній утопії Ольги Кобилянської (Feminine Melancholy. Gender and Culture in the Gender Utopia of Olha Kobyljanska) is considered the first psychoanalytic research into the artistic work and intellectual concepts of Olha Kobylianska in line with tendencies within western feminism and current gender and Post-Modern theories. This author of numerous scholarly studies on the theme of the discourse of modernism and interpretation of Post-Modernism in Ukrainian literature worked in Kiev at the Taras Shevchenko National University and at the Kyiv-Mohyla Academy, lectured at a university in Toronto, at Harvard University and at the Ukranian Free University in Munich. Her key and current works include Післячорнобильська бібліотека. Украӥнський літературний постмодерн (PostChernobyl Library. The Ukrainian Post-Modern, 2013) and Транзитна Культура (Transit Culture, 2013).

A publication by Nila Zborovska and Marie Ilnycka, which presents the newest works by contemporary authors (J. Pashkovsky, J. Andruchovych, O. Zabuzhko, O. Ulianenko) came about with the aim of mapping out the transition to feminist and gender concepts in contemporary Ukrainian literature and writing a "living" book and demonstrating that "feminism is not merely a theory but also life and a way of life." [ЗБОРОВСЬКА ЕТ AL. 1999:273].

The contemporary Ukrainian writer, literary critic and publicist Oksana Zabuzhko focuses in her work on awareness (consciousness) of Ukrainian identity, making use therein methodology from feminism and post-colonialism. Her important philosophical-literary works include Філософія Украӥнської ідеї та європейський контекст: франківський період (The Philosophy of the Ukrainian Idea and the European Context: the Franco Period, 1992) and Notre Dame d'Ukraine: Українка в конфлікті міфологій (Notre Dame d'Ukrajine: Ukraine in Conflict Mythologies, 2007).

Apart from women's questions, the work of Ukrainian female authors contain concrete expressions of anti-colonial and post-colonial resistance and this across time. If one looks at these expressions in more detail, they primarily consist of criticism of imperialism. In a similar fashion, Gayatri Chakravorty Spivak in an essay entitled 
Three Women's Texts and a Critique of Imperialism appeals to the importance of literature in the process of presentation of culture the given country. In the case of Spivak this concerns of course British literature and writers of the $19^{\text {th }}$ and $20^{\text {th }}$ centuries (Jean Rhys, Charlotte Brontë, Mary Shelley). For the purposes of this article the intersection of reactions to colonial realities and the imperial criticism in the works of Lesia Ukrainka, Olena Teliha, Lina Kostenko, Marie Matios and Oxsana Zabuzhko.

The drama work of Lesia Ukrainka best represents the aesthetics of Ukrainian modernism, it being characterized as a "European" standing in opposition to a Russian. First and foremost the dramatic poem Бояриня (Boiarynia) can serve as an example involving a linking of national feeling and anti-colonial tendencies. References to Ukrainian-Russian relations also appear in the correspondence between Lesia Ukrainka and M. Pavlyk or M. Kryvyniuk. Ukrainka compares her native land with additional European countries, often expressing in the letters regret over the fact that Ukraine is not free like other European countries, that "it dwells under the colonial yoke"[ЮРЧУК 2013: 182]. "The anti-colonial dramatic poems of Lesia Ukrainka are closely linked with feminist ideas"[ЮРЧУК 2013: 183]. The content of the works demonstrate a tendency to weaken the predominant male dominance. The works are not focused only against the Russian Czardom, but also against Ukrainian patriarchal structures. It can generally be said the heroines in the works of L. Ukrainka are active, capable and independent, prepared to fight for their beliefs, for independence and freedom. In the dramatic poem Бояриня, L. Ukrainka critiques the myth of the possible existence of the Ukrainian nation as a colony of the Russian Empire. The poem contains a generational conflict between Oxsana and Stepan in terms of the perception and implementation of one's own (Ukrainian) iden tity in terms of a form of resistance against the dictates of Russian conventions. Oxs ana refuses to "dress in Russian dresses or introduce Russian customs in her family. Dressing like a Moscovite means a loss of national identity and sexuality for a woman" [ЮРЧУК 2013: 184]. Here there is the evident importance of clothing viewed as a disguise, the false mask of the internal world of the hero. The main heroine experiences both national and sexual discrimination as being a kind of love sacrifice of the nobility she is forced to adapt to Russian aristocratic customs (including language changes to her name). Oxsana in the poem loses as a woman. She discovers that her lover is not worthy of love and she feels suppressed by two male attributes - Imperialism and Colonialism, she does not feel national freedom, she loses family harmony. Suicide becomes the only way to come to terms with the irreconcilable life situation. In theatre productions of the poem, Oxsana actually dies at the end of the play. The original written version ends with Oxsana looking at the setting sun and with the sentence 
"Good night sun, you are sailing west, you will see Ukraine - greet it from me!"2 The anti-colonial feature of the work of Lesia Ukrainka is the extra-position of the main heroine into "a foreign environment" where her nationalism and relationship to her native country become prominent.

Bolshevik totalitarianism and the mass destruction of the Ukrainian intelligentsia in the 1920 s and 1930s forced a number of Ukrainians to emigrate. One of the destinations for emigrants became Podiebrady and Prague. A pioneer in Ukrainian feminism Olena Teliha attended the Ukrainian Business Academy in Podiebrady starting at the age of fifteen and after graduation continued with her studies at the Drahomanova Ukrainian Pedagogical Institute in Prague. As a member of the Prague Ukrainian school of emigrant poets, she chose as her spiritual father Dmytro Donsov, literary critic, publicist and main ideologist of integral nationalis $\mathrm{m}^{3}$. The work of Olena Teliha has mostly been misinterpreted up until now. Only the present-day post-colonial criticism has been able to provide an integrated view of her work and a correct interpretation of her output. Olena Teliha "tried to introduce a national pathos, an anti-colonial resistance into her women's arts; this having been viewed as a male privilege" [ЮРЧУК 2013: 187]. The figures of women in the work of $\mathrm{O}$. Teliha are heroines in all of their femininity (elegant, patient, sensitive, a loving woman and mother) although, in the same way as men, they manifest national values and organise the same anti-colonial revolts. Women in the treatments of Olena Teliha have truly specific features for that time - on the one hand identifying a woman with the nation, the mother of the family and the entire nation and on the other hand a woman as a loving creature dedicated to her husband, an equal partner (the equality of women is manifested, for example, in the achieved education). In the case of Olena Teliha one can speak of a new perception of femininity, "linking femininity with masculinity, [...]"[ТЕЛІГА 2008: 92]. The prototype of the Ukrainian heroine thus emerges who is not a wild Amazon with male features or a deaf victim fulfilling all male desires, but instead a woman who is able to be a charming lover, a caring mother, a support for her husband and at the same time a defender of the family and the nation. Women in the poetry of Olena Teliha are presented as a harmonic supplement to men providing them with power for action. Woman are "a spiritual and

\footnotetext{
${ }^{2}$ Author's translation z: http://www.ukrcenter.com/ Література/ЛесяУкраїнка/19834/Бояриня, [viewing date, 8. 9. 2015].

${ }^{3}$ Integral nationalis $\mathrm{m}$ is one of the five types of nationalism according to Carlton $\mathrm{J}$. $\mathrm{H}$. Hayes, manifesting itself in a system of government by one party. An example would be Nazi Germany or Fascist Italy. It involves an attempt to unite the nation against external enemies while at the same time integrating the nation from inside through liquidation of domestic enemies.
} 
physical oasis or well in which the man-knight would go to drink." [ТЕЛІГА 2008: 20]. Teliha also touches on female sexuality in her poetry. She essentially breaks with established tradition in literature concerning the concealment of human sexual needs. A woman who understands herbody can also name her physicalneeds and can also do so in complicated periods of her life as well as in the history of her country. She would quite often link sexual ecstasy with a strong express ion of love for the nation. Love in the work of Olena Teliha has two equal forms - love for a man is identified with love for Ukraine. The poetics of the Prague Poetry School clearly presents this kind of Romantic-Nationalist concept. This is supplemented in the case of additional authors with motifs of militancy, monumental heroism and evocation of a celebrated past.

The Sixties generation in Ukrainian literature went about forming Ukrainian national identity by means of activating the historical memory. In a short period involving a temporary weakening of the Communist-Bolshevik totalitarian system, a work emerged which confirmed the Ukrainian nation in terms of its uniqueness and self-respect. The historicising theme is essential to the work of Lina Kostenko, an important Ukrainian representative of the Sixties generation, with the aim of strengthening the cultural environment of the country. According to the author herself, our genetic, historical code is fixed in the word. This idea symbolically appears in the verse novel Маруся Чурай (Marusia Churai) in the introduction in the form of burning books during a fire in Poltava in the year 1658. "If only at least one of those books had survived that fire, we would currently be able to read that ancient text. [...] Then the ancient mother, the widow, would speak to us of the sorrow with these words...'[Костенко 1999: 65]. The word would undoubtedly become the bearer of national memory, a complicated Ukrainian history.

Marusia Churai was a half-legendary Ukrainian singer and poet who lived at the time of the Cossack wars (1648-1657). She is now accepted as a romantic symbol of the struggle for faithful love and the free country. After a long wait for the return of her loved one from war, Marusia decided to commit suicide. Her loved one, Hryhorii, who forgets Marusia and falls in love with rich Poltavanka, accidentally drinks a poisonous infusion and dies. Marusia is condemned to the death penalty, however, Bohdan Khmelnytsky pardons her in his position as Hetman. The variants concerning the death of Marusia are several. What is certain is that she dies young (at the age of 28 or 27$)$.

Contemporary Ukrainian literary scholars view the importance of the work in its activation of the male and female national type. The interpretation of Ukrainian history is thereby shifted to the level of gender. Lina Kostenko presents two variations of femininity - a woman who a man feels physical (sexual) attraction to (the character 
of Halia in the novel) and a woman marked in the male world as the object of spiritual support (represented by Marusia in the novel). The first type, a woman satisfying the physical male need and the second type, a woman next to whom a man "becomes a Czar and God at the same time when he comes home" [Костенко 1999:106]. In contrast to this, Marusia evaluates her husband according to how patriotic he is, whether he would to be able to use a weapon to protect the country. In the same manner as with other works analysed here from the perspective of feminist anticolonialism, femininity as such is viewed within the family context. It always here occupies the key position of the father of the heroine, model of manliness, the model of heroism and power. After the death of the father, the symbolism of the word appears once again as a kind of protector of national history. "...He left to die, he returns in thoughts, now nobody will kill him...sometimes then on those days, shyly and casually, even if the song served him more than one sing, the sorrow first impacted the word, like a Kobzar would touch his strings..."[Костенко 1999: 99].

Marusia has an amazing artistic talent. After being betrayed in love, she also loses her divine voice, she stops singing. Her silencing is shifted to the mystical level of the silencing of all of Ukraine, thereby providing space for a deeper examination of the political and cultural stagnation in the 1980s in Ukraine 4 . Generally, the entire novel of Маруся Чурай is literally interlaced by a desire for a free Ukrainian state. This desire is manifested in this work in the following manner: Marusia stands in front of a democratic trial which confirms the existence of Ukrainian statehood, Kiev is viewed as the capitol city and additional figures in the novel present their relationship to Ukraine - a free and independent country, Marusia res pected Bohdan Khmelnytsky as the head of the country.

The novel Mаруся Чyрай deals with two issues which Ukranians were concerned about in the Soviet Union - the spiritual separation from the rest of the world and the loss of national identity. The anti-colonial focus of the novel is not a revolt against the empire, but an attempt at preserving nationality by means of mythologising Ukrainian history. The above-mentioned mythologization takes place on the level of gender - the woman (Marusia) is the bearer of the national features realized through songs and at the same time consists of a woman who wants to love and preserve the nation.

The post-colonial mythologization of the Ukrainian nation became the subject of the work of the contemporary writer Mariia Matios, a prominent figure in

\footnotetext{
${ }^{4}$ This theme is dealt with widely by Iryna Nemchenko in a paper Феномен мовчання в історичному романі у віршах Ліни Костенко "Маруся Чурай», in: Ucrainica III., Univerzita Palackého in Olomouc, 2008.
} 
contemporary Ukrainian women's prose who has an interest in issues of human existence within a feminist context, and this from two perspectives: from the perspective of a relation between a man and a woman or from the perspective of relations between individuals and society.

The novel by Mariia Matios entitled Нація (Nacija) is situated in her native mountain village of Roztoka in Bukovina and presents a piece of the national history of Ukraine. In terms of time, the novel takes place in the period of the uniting of western and eastern Ukraine when there was a strong tendency to introduce Russian traditions and rules within the territories of Volhynia, Bukovina, Galicia, Podolia and Zakarpattia. The resistance of Russification attempts was manifested in a certain ethnocentrism, and this on the level of language, culture and historical. Historical memory serves as a pillar which can be used to support all attempts at preservation of traditions and customs, first and foremost by Matios near Bukovina. These attempts are an expression of the thinking of the ethnic group, a confirmation of its existence. The past and the present are placed in strong opposition in the novel. The past consists of times involving freedom and independence, while the present represents in the novel a period of lack of freedom, punishments and fear. Mythologization of the past comes about with the memories and thoughts of the main heroes. "She would like to live freely in her mountains, not hide, - just as she lived earlier." ${ }^{\text {The forest occupies }}$ a special place in the novel. The forest represents the bearer and witness to the celebrated Ukrainian past. The main heroes of the first short stories in the novel Hauiя (Nation) Juriana and Dovhopol notice that "the forest is always the same, but something changes within them...they never allow the forest to only be us, even if the entire nation were to perish in doing so." 6 The mythologization takes place on the national level. The co-existence of the Ukrainian and Jewish nation, which is inextricably part of the history of Ukraine, is dealt with in the story entitled Апокаліпсис (Apocalypse). At the times of Imperial rule, Matios consequently declares the shared divine protection of both nations, which thereby "supports the deep religious confession of each ethnic Ukrainian"[ЮРЧУК 2013: 198]. The formation of the national Ukrainian mythologies cannot take place without polemics related to Russian Imperial mythologies which always accept everything Ukrainian as marginal, peripheral and everything Russian as central and primary. Mariia Matios therein in her novel "mythologises the western Ukrainian world as the only bearer of the marks of Ukrainian identity within the framework of the Imperial world (Russian) and the marginal colonized world (eastern Ukraine)" [Юрчук 2013:199]. From the

\footnotetext{
${ }^{5}$ MATIOC, Марія On-line book Нація: http://mreadz.com/new/index.php?id=156818\&pages=36. ${ }^{6}$ MAT IOC, Марія On-line book Hauiя: http://www.ukrclassic.com.ua/katalog/m/matios-mariya/3114mariya-matios-natsiya? start $=7$.
} 
language perspective, this opposition of two worlds the domestic/the foreign are manifested in an alternation of expressions we/they, ours/theirs. It is fairly logical that the cruelties committed by the colonizer are hyperbolized in the work. The culmination can be seen in the allegorical depiction of the sexual violence of the Russian man committed on a Ukrainian woman (either voluntarily in an attempt to protect someone or as a forced act). In the novel Солодка Даруся (Sweet Darusia) a Russian officer rapes a nursing mother. Violence can be possibly viewed, in this case, as an act directed against those who give life to children and at the same time serve as a continuer of the nation. Mariia Matios evidently chooses a woman as the heroine of her novels in order to strengthen the effect of the support of national identity. Woman is the archetype of the mother, she is a lover, a sexual object, the continuer of the nation, the protector of the family hearth and this under all circumstances and at each time.

The contemporary writer of poetry and prose Oksana Zabuzhko has become established even outside the borders of Ukraine. Her work has been translated into a number of languages and the author has received several literary prizes. Her novel entitled Польові дослідження украӥнського сексу (Field Research in Ukrainian Sex, in Ukraine 1996, in Czech 2001) introduces a completely new kind of female heroine into Ukrainian literature - a woman of completely subjective views, an open, sexual, intellectual being who "through her behaviour confirms that the period of the National Revival was an apocalyptic period in which motherhood, love and family are threatened [...], the body suffers from disease"[Гундорова 2013:209"]. Professor Ivo Pospíšil has referred to this novel which describes the sexual life of a talented Ukrainian writer during her study and lecturing visit to the USA as "the new anxiety of the turn of the millennium". There can be several kinds of anxiety. It is linked with the childhood of the heroine in a nation dependent on colonization, with the life on the borders of Ukraine and Russia, home and diaspora as well as with the psychological confrontation with a desired, but foreign environment (USA). The main heroine is followed by a KGB agent who expresses love for her and reveals the purpose for her observation. The new trauma of the heroine is revealed who by establishing an intimate relationship with a foreigner (a Russian) betrays not only herself, but also her country. The possible worst consequence of this trauma can be viewed as fear, from the relationship of the slave-master, as the reader should view it, it fathers generations which did not come about through love. "Slavery is the infection of fear. And fear kills love. And without love - even children, even poems and pictures - everything comes about with already loaded death"[Zabuzhko 2001:113]. The task of the main heroine is not only to present culture outside the borders of the country, but first and foremost to demonstrate that Ukraine has become a free country, obtaining back its lost identity and the Ukrainian culture survived and existed under new conditions. 
The Post-Modern interest in the accounts of the main heroine is als o manifested on the formal level. The difficult to translate Ukrainian text consists of lyrical stanzas, citations, English words and phrases, Polish and Russian phrases, with the text written both in Cyrillic and in Latin. Oksana Zabuzhko herself views literature as a form of national therapy and the novel Field Research in Ukrainian Sex undoubtedly demonstrates this. The main heroine confesses, cleansing both herself and those close to her. She wants to be the continuer of the nation and ethnic Ukrainian traditions, the protector of national purity. "How many of us are there actually, the unhappy, the throughout history violence impacted Ukrainian intelligentsia, - a handful, and even this is scattered: an endangered species, a half deceased clan, we should reproduce passionately and constantly,[...]"'Zabuzhko 2001:61]. The male hero of the novel is only focused on actual self-realization, they fulfil the function of victors, conquerors. Men notice the colonial load in a completely different way, further function in accordance with taught schemes, they view a woman the same continually - a sexual object serving for satisfying one's own needs.

The Ukrainian poet and the Ukrainian painter are contrasting figures and representatives of "injured Ukrainian nationalism". Both of them are aware that the Ukrainian nation is doomed to slavery. Being a woman means being subordinate to the Russian imperial influence and the Ukrainian patriarchal society is thereby subordinate to men. "[...] why did I have to be born as a woman (and even worse in Ukraine!) - with this cowardly dependence housed in a body as a time bomb, with the overall dependence, with the need to dissolve, into slimy earth, stuck on the surface of the world (from below, I always liked it - from below, smashed on its back [...]"'Zabuzhko 2001:61]. The finding of genuine men-heroes and the conception of sons-heroes, not impacted by slavery and family memory is manifested as the only path out from this colonial circle. National male power (or weakness) in the work often measures its male sexual potential. A woman needs a sexually strong and formidable partner who implants a son in her. Sex as such does not actually appear in the novel, but only in its title. The novel is focused on "Ukrainian sex which actually did not exist in Soviet Ukraine" [ЮРЧУК 2013:204]. From here the novel can be understood as evaluating attributes such as "the frigid female", "the early male impotent", "perverse teenager". Tamara Hundorová views the above-mentioned romantic and partner conflicts as post-colonial expressions. The reproduction issue linked with romantic expressions is connected with the many years of existence and the impossibility of free and natural realization of oneself. This lack of freedom exceeds the closed intimacy of two people and the causes are identified as rooted earlier and deeper. Two tendencies can be seen in the analysed novel - the suppression of everything colonial in itself and the opposition to everything which denies the existence of the nation itself. It is not surprising that Ukrainian culture has a 
greater chance in the novel to excel on the background of American and actual Ukrainian suffering linked with self-identification standing in contrast to the construed American problems.

Although the theoretical work which came about after the year 2000 on the theme of post-colonial criticism in connection with a feminist approach is in its initial phases and there is still not all that much of it, analyses of the selected works serve to confirm that the reaction to the colonial reality are evident in the works by Ukrainian female authors. The resistance to Russian tsardom, the opposition to the Ukrainian patriarchal structure can be felt in the works of Lesia Ukrainka. Olena Teliha conceives the female heroine in a new manner who no longer fits in with established structures, but who is instead expressed as an independent, free woman fulfilling the functions of a lover and a mother. The romantic experience has two levels in the work of Olena Teliha - the partner and the patriotic. Mariia Matios places her work within the territory of western Ukraine with a gradual hatred concerning the Russian occupants to the greatest extent on the sexual level. She presents heroes who are both determined and strong while at the same time being humiliated and abused by stronger Russian antagonists. Oksana Zabuzhko expands the field of activity of her heroines beyond the border of the country. Her texts are rich both in terms of post-modernism and in terms of content and in terms of the language perspective. The heroines are direct, experiencing extreme feelings, stubbornly moving toward their goals. The prose of Oksana Zabuzhko has an existential aspect containing elements of folklore along with the Romantic Gothic.

The transformations to Ukrainian women characters in the $20^{\text {th }}$ century serve to reflect the time, the artistic style, the cultural level and the historical events. The colonial experience of the Ukrainian nation impacts both the family and partner relations and the intimacy of the life of people. Family and national memory, where trauma and complexes play an essential role, need to be gradually come to terms with. The anti-colonial struggle taking place at present in eastern Ukraine amongst people arouses concern about the future, brings about fear of the future, introduces feelings of distrust and fear, represents once again the threat of suppressing independence and freedom. The trauma rooted in people from earlier periods acquires new dimensions, both deepening and devastating the specificity and authentic face of the Ukrainian nation. 


\section{BİBLİOGRPHY:}

Гундорова, Тамара. Транзитна культура. Київ: Грані-Т, 2008. Print.

Гундорова, Тамара. Післячорнобильска бібліотека. Укрїнський літературний постмодерн. Київ: Критика, 2013. Print.

Зборовська, Ніла. end ІЛЬНИЦЬКА, Марія. Феміністичні роздуми. На карнавалі мертвих поцілунків. 1999 Web. 18 Мау 2016.

Костенко, Ліна. Біографія. Вибрані поезії. Маруся Чурай. Інтерпретація творів. Кіровоград: Степова Еллада, 1999. Print.

Наєнко, Михайло. Історія українського літературознавства: Підручник. Київ: Академія, 2001. Print.

Павличко, Соломія. Фемінізм. Київ: Основи, 2002. Print.

Рябчук, Микола. Постколоніальний синдром. Спостереження. Київ: K.I.C., 2011. Print.

Теліга, Олена. Вибрані твори. Київ: Смолоскип, 2008. Print

Юрчук, Олена. У тіні імперіi. Українська література у світлі постколоніальної теорії. Київ: Академія, 2013. Print.

Zabuzhko, Оксана. Polní výzkum ukrajinského sexu. Trans. Rita Kindlerová. Havlíčkův Brod: One Woman Press, 2001. Print. 